\title{
How the savagism of motorbike culture has shaped the narco city
}

\author{
C. M. Jaramillo \\ University of Edinburgh, UK
}

\begin{abstract}
The narco-motorbike is often identified by Medellinenses as a red Yamaha. This vehicle is not only a means of private transport, but it is also used for committing crime by the traffickers. This mode of transport represents a culture of success, death and ambiguity between 'good' and 'bad.' This research studies the evolution of the culture of this vehicle in Medellin by looking at how the narco motorbike has changed the city and how the competitive environment of capitalism and symbiosis with the machine could end in a violent city inside a 'capitalist paradise.' This analysis observes the evolving narco-motorbike from historical, architectural, biological, technological and anthropological perspectives, and the complex relations between popular culture, urbanism, transport and social media. The aim of this research is to understand how the motorbike culture originates in the first place and how the narco-motorbike has influenced the contemporary city.

The methodology was an inductive approach because the theory came from analysing the case study first. This analysis is done by using the 'multilinear evolution,' which essentially studies the significant alteration of a particular culture, so a cultural law should be identified. The result of this study was that the motorbike is frequently seen as a criminal object. Instead, of avoiding the motorbike, Medellinenses seem to consider it as a way to protect themselves from the sicarios. This new urban culture might be seen as a magnetic attraction because basically, the contemporary motorbike culture encapsulated a cultural polarity.

Keywords: private transport, motorbike, Medellin planning, Medellin Cartel, Pablo Escobar, sicario, terrorism, cultural evolution, South American and social media.
\end{abstract}




\section{Introduction}

Speed of the motorbike represents 'maximum power that at a given time and in a given exercise can be accomplished by man' [1, p. 231]. In other words, speed is related with productivity and the fitness of individuals. In more detail, the motorbike race was described by Morasso as a gladiator game because this spectacle 'has ever made such as great, continuous, mortal risk integral to its own existence [1, p. 232].

Moreover, the motorbike in Medellin also produces culture, which seems to be an 'information such as knowledge, beliefs, and values that is inherited through social learning and expressed in behavior and artifacts' [2]. Historically, the narco motorbike in Medellin symbolised the 'the culture of death' [3]. A symbol is described as a form which is abstract information over generations and accumulates over time [4, p. 59]. This vehicle could also compare with the significance of a primitive mask, which is described by Boas as an object, which can have different meanings and purposes [4, p. 41]. In other words, the motorbike is not only a vehicle of transport; it can also communicate a cultural evolution.

Data collection came essentially from observations, and the internet played an important role in the investigation of the contemporary phenomenon because social media is seen to be an important form of communication and the motorbike is not only a physical machine in the city, because this vehicle connects the physical world with the virtual world. Most data collection came from observing public Facebook and Zello groups; moreover, any private information was not considered. These resources supplied mostly photos, audio content, written comments and videos. Google air was also used to study particular areas. Reports and statistics were from national sources; some of these bodies were the Plot, Facebook groups, Dane, Fenalco and Alcadia de Medellin. Other data have also been collected from national magazines and newspapers: El Tiempo, El Colombiano, El Expectador and Semana.

Finally, this paper is divided into different sections: it begins with 'History of the narco motorbike,' which is briefly the history of the narco motorbike in Medellin. It continues with 'The culture of the narco motorbike,' to discuss and explain the cultural influence of the narco motorbike in the city. It then follows thought 'Contemporary chaos of the motorbike culture' which studies the contemporary motorbike culture in the urban space. Finally, 'Hunting rats in the city' explores the violence of the ordinary motorcyclist when reacting to robbery.

\section{History of the narco motorbike}

The narco motorbike started when Medellin in the 1980s turned from the 'capitalist paradise' [5] into the 'Capital of Cocaine' [6] as a result of the actions of Pablo Emilio Escobar, who was described by an informer in a FBI report as 'the third richest man in the world' and the 'drug king of the world' [7]. He was called 'el patron,' because he was apparently the boss in this capitalist side of the city.

The motorbike in this case was a consumer product of Escobar and the demand came from his anonymous groups, the 'extraditables.' Officially, they preferred 
death instead of going to American prisons [8, p. 82]. The 'extraditables' forced politicians to choose money over death [8, p. 86]. Death might be the most powerful tool of control and intimidation, because it can remove opponents. Deleuze saw this human instinct in contemporary society, when he said that 'there is no need to fear or hope, but only to look for new weapons' [9].

The narco motorbike seemed to start with the Esternbergef School. Initially, Isaac Guttnan Esternbergef trained 50 mercenaries in 'Sabaneta' for a period of seven years. The final school examination could require the killing of an ordinary civilian. Moreover, the legendary cross shooting technique of Esternbergef might be its biggest contribution because it is a technique where crossing the arms can improve the marksmanship of the bike rider. A consequence of Esternbergef school was the influence of two gangs: 'Los Quesitos' and 'Los Priscos.' Probably the Priscos had more impact on the local culture; however, the Quesitos committed the historical murder of Lara Bonilla [10].

Officially, the catastrophe of the narco motorbike started when Lara Bonilla, the Minister of Justice, was killed by a sicario on a narco motorbike. As a result, the DT 175 red Yamaha became to be known as the 'killing minister' [11]. The murder of Lara was a complex crime because Lara had six bodyguards inside two cars [8, p. 73]. One car was in front of Lara's white Mercedes Benz W123 and the other car was at the back [12, p. 115].

Lara's murder has had significant consequences for national politics because his death showed a weak government, which could no longer control terrorism. The next day when El Tiempo, the local newspaper, published the photo of the 16year old teenager, who drove the motorbike [13], Medellin and the rest of Colombia were in shock: how could teenagers kill a minister?

\section{Culture of the narco motorbike}

Essentially, using the motorbike in crime defines 'the culture of death,' [3] where murder was just seen as 'a job done' [12, p. 145]. Priests mentioned that sicarios often confessed that they didn't feel guilty after a crime because the criminal for them is the person who orders the crime [14]. It has been well defined in Our Lady of the Assassins when the protagonist asks a pregnant woman, who screams during the murder, 'what happened to you? Have they done anything to you? Not to me, but he killed the motorcyclists, so what? This is not the first time. We don't live in Switzerland, and instead, we live in Medellin' [15].

The culture of the narco motorbike is perceived as based on a contradiction between two things: the criminal structure and the traditional Catholic faith [16]. In the past in Medellin, the church organised the textile industry workers, which led to the ambiguity of integrating religious symbols into consumerism. This paradox was an obvious characteristic of Richard from Los Priscos, who was described as the leader of the most powerful crime industry in Colombia in the 1980s [17]. He was an individual who went to mass every day [18] and there was a metre-high statue of Virgin Carmen outside his home [12, p. 144]. Furthermore, it has been speculated that the money for paying for the Virgin came from money which had been acquired from his first murder [19]. 
Moreover, the role of the motorbike in the society is similar to the 'parlache' because both initially came from the narco city. This parlache was slowly developed, for example in local tango places in Manrique. Afterwards, this local language was taken over by the sicario [20, p. 527]. The parlache defines a new society $[20$, p. 526], whose vocabulary is more about death, weapons, money, drugs and the ephemeral life [20, p. 531].

Another part of the process by which the narco motorbike culture changed the society was the fact that Escobar's personal sicarios were symbols of power, financial comfort and the upper class. This can be understood by looking at Escobar's 'apparatus,' which operated in the same way as some multinationals, because it provided good salaries, bonuses, and medical insurance. Escobar was described as a generous boss; he could give sicarios a country house, a share in a trafficker's business or raise salaries [12, p. 144].

In particular, a boy from Medellin's shantytown described Escobar's sicarios as a symbol of prosperity because they were seen as those who had the best cars, weapons and excess in general [21, p.72]. For example, Pinina (John Jairo Arias), who was from Aranjuez [22] was considered one of the most important sicarios of Escobar's corporation [23]. He achieved a fortune, which was estimated at two million dollar in ten years. He owned properties in Poblado, Estrella, Caldas and Rionegro [12, p. 245].

The 'kindness' from sicarios and from traffickers in general might have changed the local morality and might also have helped to spread the narco motorbike culture too. Local parties were organised by sicarios, which could explain how the local morality changed. The reason behind this was that the local people did not see that the sicario was related to his crime, because eventually the 'kindness' was more visible, as the sicario celebrating 'a job done', would spend money in his local community. A good example is 'Los Priscos' who organised big communal parties in Aranjuez. They closed the street and brought music and food for the community [12, p. 145].

\section{Contemporary chaos of the motorbike culture}

Commonly this mode of transport can be seen as an 'urban assault vehicle' [24, p. 304]. For example, Stephen thinks that the message of the Hummer, a luxury SUV, is: 'don't mess with me because I can crush you, I can kill you right away, so don't approach me, hah' [24, p. 320]. The narco motorbike message is similar because the sicario used to say 'too bad for him who crosses my path' [25].

These two modes of transport have in common a vision of a city where individuals 'have rights to be 'left alone' on city streets, rights previously applied (in America) only to the property and Stephen described this point as 'privatized juridical individuals' [24, p. 314]. In synthesis, individuals have found new strategies to run the existing capitalism and disassembling the city into individuals to become a materialistic city.

The disassembling the city into individuals caused by motorbikes is perfectly explained by a recent video, which shows that the metro bus on Manrique Road, 


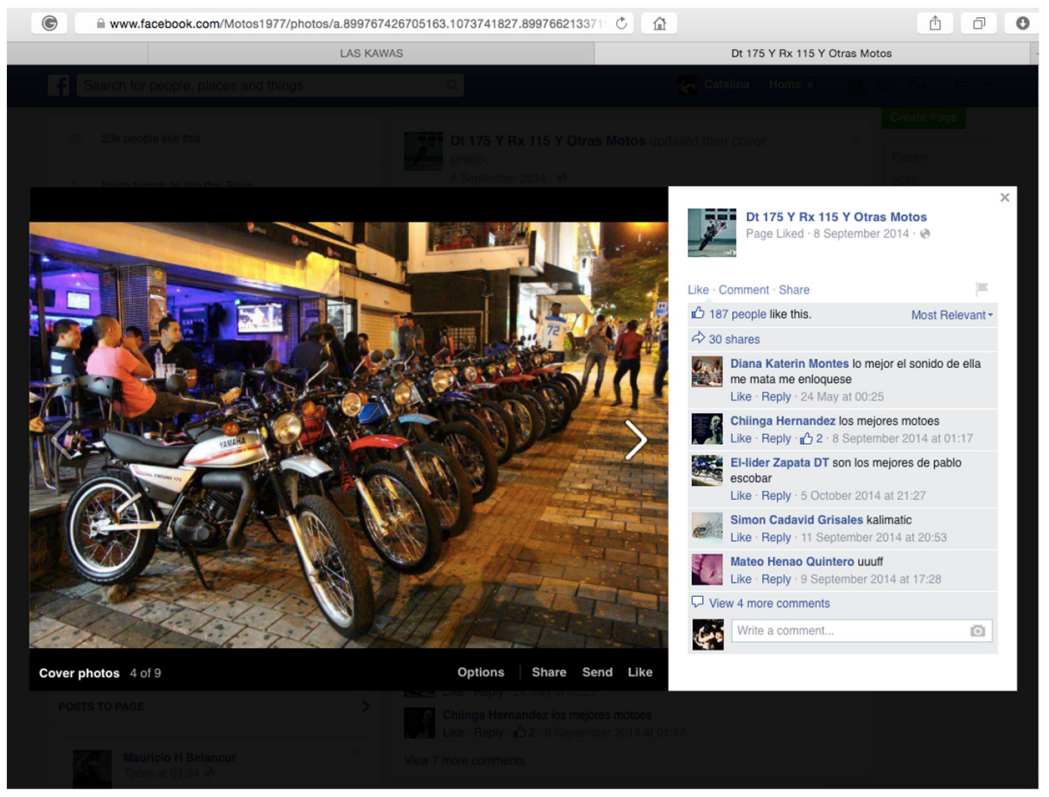

Figure 1: Photo from a Facebook profile; the motorbike clearly played an important role in the public space. All the motorbikes are the famous Dt, which was the traditional Yamaha model used by sicarios [26].

intended exclusively as a bus route, has not been respected by the motorbikes. As a result, 93 transit accidents were reported in June 2015. One woman comments on a Manrique Facebook page that it was a bad idea to close this busy road because the metro bus is only for individuals, who are not busy enough; another woman asked how it is possible that only local bus services can use a local road [27]. It seems that the civic education aims of the metro cable and Medellin metro have not succeeded with the metro bus, which also questions the role of the street in the local community because of the economical value and privatization of the street.

Other examples of this urban chaos caused by motorbikes is the popular illegal practice of 'piques' or wheelies in streets performed by teenagers. The most popular streets are Las Palmas, la 80 and the local street. 30 law enforcement operations were carried out in 2015 [28], but the council admitted that stunt ride is still a pedagogic, popular and cultural activity. For that reason, the local government would like to promote the practice in designated areas [29].

\section{Hunting rats in the city}

"Socrates, asking a definition of justice from his compatriots, received two answers: 'justice is doing good to friends and evil to enemies;' 'Justice is nothing else than that which is advantageous to the stronger" [30]. 
Speed of the motorbike probably covers the needs of medellineses middle class because today, the motorbike is clearly not exclusive to sicarios. Instead, the reality is that the motorbike is more representative of the ordinary working class. Moreover, this vehicle is a fundamental tool for the Colombian individuals of lower income since it improves their quality of life. Statistics clearly illustrate this point because $70 \%$ of motorcyclists are workers and $73 \%$ have finished school and have technological training. Also, 21\% need the motorbike for working in Medellin, because this vehicle conveys the most deliveries [31]. In 2004, Medellin had 178,000 motorbikes, but in 2015, there were 600,000 [32].

In the past, most working classes thought that an individual needed to be a competitive worker in order to be a decent person. Past policies of Berrio [33] created a paradigm between the working individual and the unemployed. Finally, this local context polarised the society because it produced more competitive and productive individuals, in contrast with the mechanisms of social selection or social cleansing [21, p. 45, 88]. In fact, numerous sicario confessions were observed that murder is not a crime unless the victim is considered a 'good person' [14]. Moreover, today, thieves are considered by the local motorcycle community to be 'rats' who need to be exterminated. The word rat is used to describe somebody who is without scruples. Ironically, a rat is also a corrupted politician.

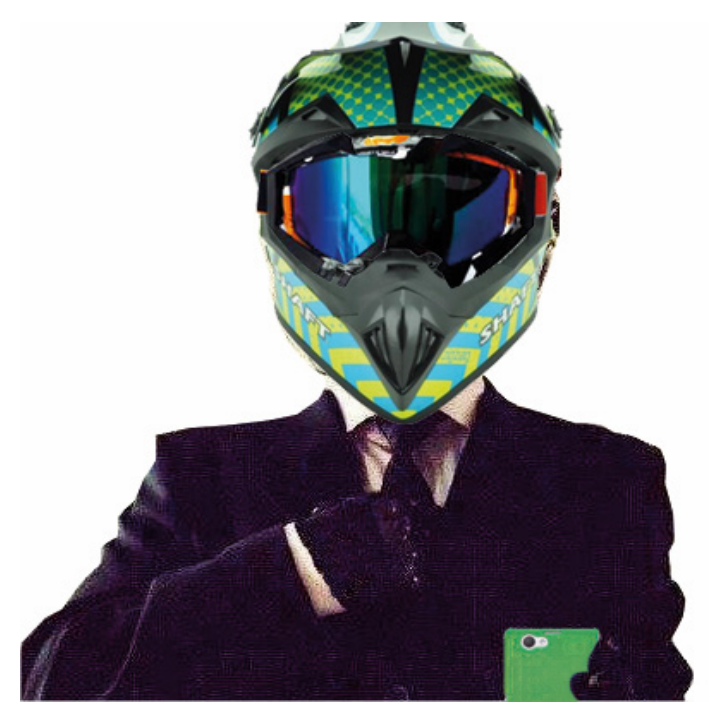

Figure 2: Gestalt of the contemporary motorcyclist's culture.

These mechanisms of social selection or social cleansing can be observed in the contemporary motorbike groups who attack thieves because motorbike robberies increased. It increased to $53.3 \%$ and 8,338 motorbikes were stolen by August 2015 in Medellin [34]. Moreover, stolen motorbike is more profitable industry than carjacking because it is possible to dismantle motorbikes and then sell the motorbike as parts without the associated registration papers. 
In some cases these physical attacks are severe; some of them use helmet and sticks. Ironically, sometimes the police need to save the thief from the civilian attacks. These attacks are purposely recorded to share on social media and the most common media seems to be Facebook. The main characteristic of these Facebook groups is the support and occasionally, the comments tend to be more violent than the videos. In some way, they are hits; people are obsessive about persecuting 'sicarios.' They want to show the thief's face because they need to ridicule him and make him feel ashamed, pain and embarrassment.

One such attack happened in Prado, Medellin's centre, and it was initially published on Facebook where one of the sharing sources wrote: 'beauty; ha ha the blood was not spilled. The video showed five individuals attacking a thief, who in theory was trying to steal a motorbike. The most shocking moment is when the owner of this vehicle attacked the thief fiercely with his helmet. On 5th July 2015, the page had 27,842 viewings after seven hours of being published in one group and 1,630 shares were posted on the uploaded profile. Eventually, it appeared on Caracol, the national television channel [35].

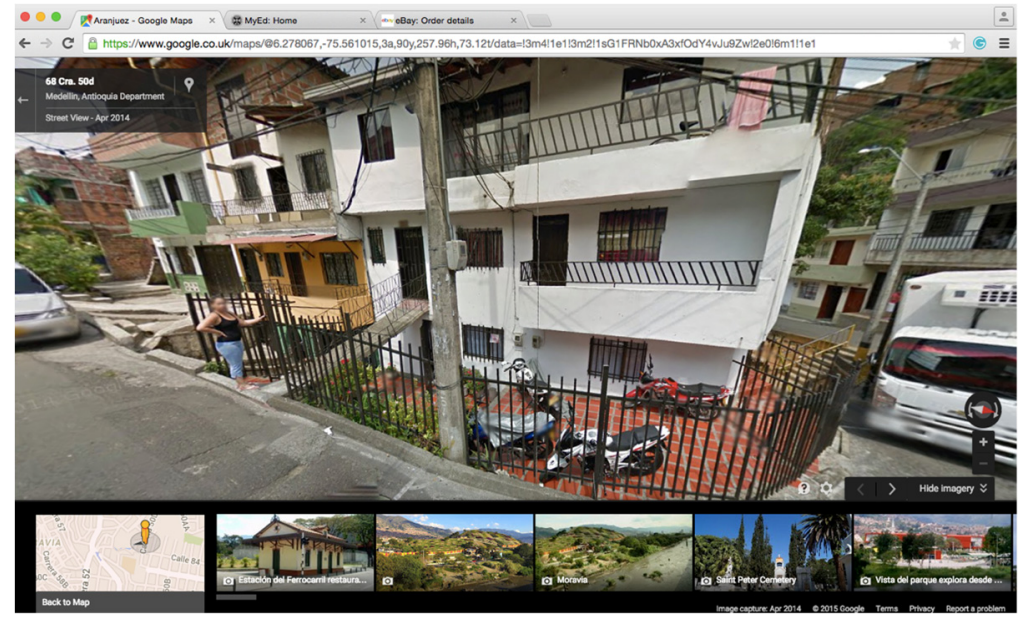

Figure 3: The motorbike seems to play an important role in the local communities. Photo from Google view from the address of Aranjuez, 68cra. 50d [38].

In the end, the stolen motorbike industry has promoted new opportunities for a new industry of security systems because Facebook groups started from post videos and free support to sell GPS and offer support to recover stolen motorbikes. Moreover, Motorbike manufacturing is a profitable industry because the motorbike industry generates $8.3 \%$ of local jobs [36]; its profits last year were 2 billion Colombian pesos and contributed 5\% of the income growth in 2014 [37]. Urban land use and layout in Medellin is also affected by the increased market of the motorbike industry. The motorbike is a booming industry, which has adapted the street to its needs. In particular, motorbike shops are identified in two main 
epicentres of retailing: 38 Street and 10A Street, Poblado. Moreover, this local market has promoted motorbike repair shops in local communities [38]. For example, motorbike shops have developed into commercial areas, and car parks and footpaths have been dramatically reduced.

\section{Conclusion}

The contemporary motorbike culture might involve some kind of evolutionary arms race, which has been described as a mechanism of evolution. In theory, this survival race is between the predator and the prey. It is an act of attacking and defending. 'Alexander along with Humphrey (1976) see human evolution as involving a kind of arms race for intelligence. New strategies and still newer counterstrategies for social interaction are the only formula for success in the environment of ever-shifting confluences and conflicts of interest that are characteristic of human society' [39]. As a result, both competitors have the capacity to create new mechanisms of survival. Dawkins and Krebs describes this mechanism as the process by which 'submarine designers learn from earlier failure. As technology progresses, later submarines are better equipped to detect and sink ships. And later-designed ships are better equipped to resist' [40].

In more detail, the motorbike culture is a variable because it '[has] some sort of effect on the differential probabilities of survival of social relationships' [41, p. 85] and it might involve two mechanisms of cultural evolution, which were explained by Allard as the 'mechanism of variation' and the 'mechanism of continuity' $[41$, p. 9]. The polarity of both mechanisms seem to integrate into one new culture, which defines the contemporary ordinary motorcyclist. The 'mechanism of continuity' could be described as transmitting the narco motorbike culture because Escobar's personal sicarios were symbols of power, financial comfort and the upper class [12, p. 144].

However, the motorbike presented a second mechanism, the 'mechanism of variation' [41, p. 9], which 'arises through errors or improvisation in learning and distortion in transmission' [2]. Wallace's theory about the 'revitalization' could explain cultural distortions from the stress produced from a catastrophe. Medellineses replace the urban reality, but change the gestalt and the mazeway, which is described by Wallace as 'nature, society, culture, personality and body image' [42] because the contemporary motorbike might be more similar to Body Armor Superman because apparently, the ordinary motorcyclist believes that they can protect the city like the hero.

Taylor said that any culture is not a new creation because 'it is a result of past times' and, yet showing 'in the case of survival clear vestiges of the course of its development' [43]. If time could reverse and remove variants of a culture, the society would be completely different. 'Humans produce culture, but we are also a product of culture' $[4$, p. 56]. The narco city had shaped the contemporary city because Medellin seems to present vestiges of the narco motorbike in an unpredictable way. 


\section{References}

[1] Morasso, M. Sensation of Speed. In Speed Limits, edited by Jeffrey T S, Skira, Milan (2009).

[2] Mesoudi A, Whiten A, Laland K. "Perspective: is Human Cultural Evolution Darwinian? Evidence Reviewed from the Perspective of the Origin of Species". Evolution. pp. 1-11 (2014).

[3] Jaramillo A, Salazar A. La Subculturas Del Narcotrafico, Cinep, Medellin. p. 107 (1992).

[4] Perry, R J. Five Key Concepts in Anthropological Thinking, Prentice Hall, New Jersey (2003).

[5] Kessel, D. "Photographic Essays: Medellin: South American Showplace," Life. p. 109, 29th September, 1947.

[6] Borrell, J. 'Colombia the Most Dangerous City Colombia Welcome to Medellin, Coke Capital of the World', Time. Vol. 131 Issue 12. p. 3 (1988).

[7] FBI, Pablo Escobar Part 1 of 8, https://vault.fbi.gov/pablo-escobar/ Pablo\%20Escobar\%20Part\%205\%20of\%208\%20 p. 7, 4th May, 1984.

[8] Mollison J, Nelson R. The Memory of Pablo Escobar, New York, Chris Boot (2009).

[9] Deleuze G. "Postcript on the Societies of Control," vol. 59, MIT. p. 4. (Winter, October, 1992).

[10] Castillo, F. Los Jinetes De La Cocaina, ed. fist edition, Editorial documentos periodisticos, Bogota. p. 81 (1987).

[11] Andres, Cual Es La Verdadera (Lara Bonilla) O Mata Ministros, La Mejor Yamaha.com, http://lamejoryamaha.com/que-tiene-mi-dt/ 26th November 2014

[12] Cañon L, El Patron: Vida y Muerte de Pablo Escobar, Planeta, Bogota (2001).

[13] “Asesinado Ministro De Justicia," El Tiempo, Bogota. p. 1. Tuesday, 1st May 1984

[14] Semana. "Yo Pecador..... Los curas antioqueños nos saben que hacer con lo que estan oyendo en las cofesiones de los sicarios," Bogota, http://www.semana.com/imprimir/13140 (1990).

[15] Schroeder B, "La Virgen De Los Sicarios," Colombia, Francia: BIM Distribuzione (2000).

[16] Salazar, A. Pablo Escobar, El Patron Del Mal, Santillana, Florida. pp. 117118 (2012).

[17] Acero G. 'La Mas Temible Industria Del Crimen', El Tiempo, Bogota. https://news.google.com/newspapers?id=jsUcAAAAIBAJ\&sjid=iVkEAA AAIBAJ\&pg=1184\%2C2280207 p. 1. 7th August 1987.

[18] Serrano A. Multinacional Del Crimen La Tenebrosa Oficina De Envigado, Pinguin randon house, Bogota, p. 50 (2010).

[19] Nullvalue. "El Que a Hierro Mata A...." El Tiempo, http://www.eltiempo.com/archivo/ documento/MAM-13995 (1991).

[20] Castaneda L. E., Henao J. I. "El Parlache : Historia de la Ciudad." ed. Jaramillo M. M., Osorio B., Robledo A. I., trans. IV Culture popular, vol. 3- 
4, Literatura y cultura: narrativa colombiana del siglo XX, hibridez y alteridades, Ministerio de Cultura, Bogota, http:/www.Banrepcultural.org /sites/default/files/lablaa/literatura/narrativa/Volumen3CapIV.pdf (2004).

[21] Jaramillo A, Ceballos R, Villa M. En la Encrucijada, ed. First edition, Corporacion Region, Medellin. (1998).

[22] Legarda A, Velasquez J. El Verdadero Pablo: Sangre, Traicion y Muerte. Ediciones Dipon/Ediciones Gato Azul, Bogota, p. 37 (2005).

[23] Semana, "Golpe al Sicario", Bogota http://www.semana.com//nacion/ articulo/golpe-sicariato/13607-3. p.1. July 1990.

[24] Graham, Stephen. Cities under Siege, Verso, London (2010).

[25] Salazar A. Born to Die in Medellin [No Nacimos Pa'Semilla], trans. Caistor N, Latin America Bureau ltd, London, p. 16 (1990).

[26] Dt $175 \mathrm{Y}$ Rx $115 \mathrm{Y}$ otras Motos, Facebook, www.facebook.com/ MOTOS1977/photos/a.899767426705163.1073741827.899766213371 (2014).

[27] H13N, "En la 45 de Manrique van 93 accidentes en lo va del año 2015," Manrique- Medellin- Antioquia-Colombia, Facebook, https://www.facebook.com/ManriqueMedellinAntioquiaColombia/videos/ 9082737792461/ 20th July, 2015.

[28] Arango C. "Piques De Motos, ¿Qué Tan Controlado Está El Tema?”, El Colombiano, Medellin, http://www.elcolombiano.com/piques-de-motosque-tan-controlado-esta-el-tema-KG2800950 (2014).

[29] Martínez R. "En Medellín Autorizan Piques En Motos, motorbike”, El Colombiano, Medellin, http://www.elcolombiano.com/en-medellinautorizan -piques-en-motos-XH3119321 (2015).

[30] Keith, Sir Arthur. A New Theory of Human Evolution, Watts \& Co, London. p. 121 (1948).

[31] Fenalco; Investiga, "Boletin Economico Sectorial, Sector Motos," in Boletin economico Sectorial, Medellin, p. 1 (2012).

[32] Pareja D. "No Se Descarta Carril Exclusivo Para Motos En Medellín Medellín,” El Tiempo. http://www.eltiempo.com/colombia/medellin/no-sedescarta-carril-exclusivo-para-motos-en-medellin/14660896 9th October 2014.

[33] Alvarez J, Paisa Memorias De Un Pueblo, in Paisa Memorias de un Pueblo, Tiempos Modernos, Antioquia goverment, Medellin (2005).

[34] Olivares S. "Muchas Motos y Poca reduccion del Crimen, “Q’ubo. pp 8-9 (2015).

[35] Noticias Caracol. "Supuesto Ladrón Recibió Tremenda golpiza en el barrio Prado centro de Medellín", Bogota, http://www.noticiascaracol.com/ medellin/supuesto-ladron-recibio-tremenda-golpiza-en-el-barrio-pradocentro-de-medellin. (2014).

[36] Fenalco; Investiga. Boletin Economico Sectorial, Sector Motos, Medellin, p. 4 (2014).

[37] Fenalco, Investiga. Boletin Economico Sectorial, Sector Motos, Medellin, p. 2 (2015). 
[38] Google. 68cra. 50d, Medellin, Colombia Google Map, https:/www.google.co.uk/maps/@6.2780668,-75.561015,3a,75y,273.97h, 71.06t/data=!3m6!1e1!3m4!1sG1FRNb0xA3xfOdY4vJu9Zw!2e0!7i13312 !8i6656.

[39] Irons W. "How Human Has Evolution Shaped Human Behavior? Richard Alexander's Contribution to an Important Question, "Evolution and Human Behavior”, Elselvie. Doi:10.1016/j.volhumbehav.2004.08.016 p. 5 (2004).

[40] Dawkins R; Krebs J “Arms Races between and within Species", Procedings of The Royal of Society 205, no. 116. doi: 10.1098/rspb.1797.0081 p. 489 (1979).

[41] Langton, J. "Darwinism and the Behavioral Theory of Sociocultural Evolution: An Analysis", American Journal of Sociology (1979).

[42] Wallace A. Mazeways, Essays of Culture Change, Volume 1, ed. Grumet R, Lincon, University of Nebraska. press, pp. 11-12 (2003).

[43] Laavanyan R. E.B Tylor and the Problem of Primitive Culture, History and Anthropology, Routledge. doi: 10.1080/02757200802320934 pp. 136-137, 15th August 2008. 